\title{
Divulgação e Educação Científica Racista no Boletim de Eugenia (1929-1933): Uma Análise Crítica com Vistas a Contribuir para uma Educação em Ciências Contemporânea
}

\author{
Racism in Education and Dissemination of Science in the Bulletin of Eugenics \\ (1929-1933): a Critical Analysis for Contemporary Science Education
}

Nivaldo Aureliano Léo Neto

\begin{abstract}
Palavras-chave Resumo A História, Sociologia e Filosofia das Ciências Biológicas Raça; se constituem em importantes meios pelos quais podemos analisar Racismo; criticamente o processo de constituição da Educação em Ciências. Relações étnico- No Brasil, pelo menos desde o final do século XIX, circulavam raciais; teorias científicas que enfatizavam a segregação racial a partir de História da Ciência. uma argumentação biológica. Exemplo de uma dessas organizações científicas são as Sociedades Eugênicas e o Boletim de Eugenia, publicação impressa existente entre os anos de 1929 a 1933. A presente pesquisa parte da análise dos 42 números do Boletim de Eugenia, publicados entre os referidos anos, reconhecendo essas publicações enquanto estratégia de divulgação científica na qual se propagandeava uma educação eugênica na sociedade brasileira. A partir da análise empreendida e tendo como ferramenta analítica o conceito de Necropolítica do filósofo Achille Mbembe, foram destacados elementos discursivos com foco para os processos de racialização da população e da consequente discriminação segregativa produzida pelo elemento padronizado (pessoas consideradas "brancas") para o desviante (pessoas negras e/ou aquelas consideradas, na linguagem utilizada à época, "pessoas de cor”). O artigo se estrutura em três seções, apresentando conceituações gerais sobre Eugenia e Eugenismo, os elementos narrativos que propunham programas curriculares de educação eugênica e o incentivo a Educação Sexual como estratégia eugênica. Se eticamente uma educação antirracista deve ser de responsabilidade de todas as áreas do conhecimento, cabe às Ciências Biológicas, entre possíveis atitudes, analisar os processos históricos que constituem suas bases epistemológicas, identificando possíveis permanências, em suas práticas cotidianas, das estruturas racistas.
\end{abstract}

Submetido em 17 de agosto de 2020 
Keywords Abstract History, Sociology and Philosophy of Biological Sciences

Race; are important ways to critically analyze the process of constitution of

Racism; Science Education. At least since the end of the 19th century, scientific

Ethnic-racial theories that emphasized racial segregation based on biological relations; argumentation circulated in Brazil. One such scientific organization

History of Science. was the Eugenic Societies and the Bulletin of Eugenics, a publication printed from 1929 to 1933 . This research starts is based on the analysis of all the 42 issues of the bulletin, recognizing these publications as a strategy of scientific dissemination of eugenic education in Brazilian society. With this analysis and using philosopher Achille Mbembe's concept of Necropolitics as an analytical tool, we investigated discursive elements on the processes of racialization of the population and the consequent segregation produced by the standardizing element (people considered "white") against the deviant (black people and those considered, in the language used at the time, "people of color"). The article is structured in three sections, presenting general concepts about Eugenics and Eugenism, the narrative elements that proposed eugenic curriculum programs and the encouragement of Sexual Education as a eugenic strategy. If all areas of knowledge should be ethically responsible for an anti-racist education, it is up to the Biological Sciences, among possible attitudes, to analyze the historical processes that constitute their epistemological bases, identifying possible persistency of racist structures in daily practices.

\section{Introdução}

Para compreender a formação da sociedade brasileira ao longo das diversas situações históricas, precisamos tomar como premissa questões relativas aos entendimentos sobre a Raça. Especificamente, enquanto Estado-Nação, o Brasil se configura em seus arranjos estruturais enquanto um Estado-Racialista (Guimarães \& Drumond, 2018). As experiências inter-raciais da miscigenação (suscitada historicamente, em grande parte, por violentas relações de estupro e consequente violação do corpo das mulheres negras e indígenas) foram objeto de estudo por parte de vários autores e autoras visando a compreensão da formação do Estado e suas relações de violência (Munanga, 1996). Pensar as formações de políticas fundamentadas nos critérios raciais e as consequências para o processo civilizatório advinda das mesmas, nos indica as estratégias que o EstadoNação conduz para o controle do que é percebido enquanto diferença e o ocultamento do que é representado como padrão (neste caso a heterocisnormatividade branca).

No Brasil, com o advento da República e a noção de soberania nacional, "intensificam-se as expectativas de progresso nacional, mobilizando as elites urbanas a buscarem na ciência os recursos para a identificação das causas dos problemas nacionais 
e os meios de enfrentá-los (Bonfim, 2019). Grande parte da intelectualidade brasileira foi mobilizada na discussão sobre o caráter da identidade nacional, no qual os cuidados com a família e a infância convertiam-se em categorias privilegiadas de análise no quadro das preocupações com a nacionalidade (Bonfim, 2019). Articulados em torno de associações, ligas, comissões e sociedades, essa intelectualidade redigia manifestos e campanhas frente a crescente frustração com a condução do regime republicano.

Palestras, conferências e cursos, enquanto modalidades de divulgação científica, foram conduzidas entre os anos de 1870 a 1889 em instituições de pesquisa na cidade do Rio de Janeiro, à época centro econômico do Império (Carula, 2016). Era intenso o medo da população branca brasileira frente a uma possível insurgência dos povos negros (até então regidos sobre um sistema escravocrata amparado na legislação) devido a todas as violências sofridas. Nessa época, o Brasil se configurava um dos últimos países a manter o sistema escravocrata. Na Assembleia Legislativa de São Paulo, discutia-se a transição para um trabalho assalariado, não pelo fato da reparação histórica, mas ao contrário, no de incentivar a imigração branco-europeia em negação a população negra (Azevedo, 1987).

Publicações científicas, boletins, almanaques, revistas ilustradas e demais publicações impressas também tiveram ampla circulação (algumas com curto período de duração) nesse período e em anos vindouros. Constituíam-se enquanto meios para uma educação científica que visava principalmente atingir determinados setores da sociedade letrada brasileira e que, não necessariamente, possuíam conhecimentos básicos em Ciências. Exemplo de uma dessas publicações consiste no Boletim de Eugenia, cujos números mensais foram veiculados entre os anos de 1929 a 1933.

O presente estudo tem como objetivo principal analisar as publicações do Boletim de Eugenia (enquanto meio de divulgação e educação científica), especificamente os esforços para uma campanha de educação eugênica através das Ciências Biológicas. A partir disto, elencam-se noções que indicam estratégias racistas para o extermínio de uma parcela da população brasileira considerada desviante de um padrão. Ao longo da análise, perceberemos como tais representações, sobre as "pessoas não brancas", guardam semelhanças com a contemporaneidade brasileira, o que pode demonstrar a permanência e plasticidade do racismo enquanto sistema de opressão que estrutura privilégios.

Carlos e Dietrich (2018) pensam o estudo da Eugenia, através da História da Biologia, como uma proposta para o Ensino de Ciências e Biologia que busque refletir sobre as produções históricas e políticas do conhecimento científico, relacionando-se dessa forma a uma perspectiva de Educação em Direitos Humanos. Para Verrangia (2014, p.11), "o ensino de ciências incorpora uma forma de propaganda racista sutil, difícil de ser detectada, principalmente tendo em vista que essa forma de conhecimento é comumente percebida como politicamente neutra”. No Brasil, a institucionalização do Ensino de Ciências e Biologia enquanto componente curricular obrigatório da educação básica passou por adequações ao longo dos anos até chegarmos aos moldes atuais. 
Situando a pesquisa no Ensino de Ciências e Biologia voltado à educação para as relações étnico-raciais, Verrangia (2014, p. 22) estabelece sete pontos indicativos para uma agenda de pesquisa que procura "contribuir na compreensão do papel que a educação científica pode ter na construção de uma escolarização que contemple efetivamente a diversidade étnico-racial que compõe nossas sociedades".

Neste artigo, ao se analisar os exemplares do Boletim de Eugenia, busca-se colaborar mais diretamente em pelo menos três desses pontos referentes a uma agenda de pesquisa na Educação em Ciências para as relações étnico-raciais. São eles: (1) o papel que as Ciências Naturais possuem na construção de relações sociais injustas, entre elas a étnico-racial; (2) currículo, educação em ciências e relações étnico-raciais, envolvendo histórias de disciplinas escolares, programas e políticas de materiais didáticos; (3) estudos sobre a mídia, divulgação científica e a educação das relações étnico-raciais (Verrangia, 2014). Trabalhos de análise histórico-documental, como o que aqui é apresentado, contribuem para a área da pesquisa em Educação em Ciências quando, por entre as descontinuidades históricas, podemos perceber as permanências de práticas indesejáveis (a exemplo da discriminação racial).

Após a apresentação do percurso metodológico e das categorias analíticas centrais para a linha de reflexão, os resultados da análise dos números do Boletim de Eugenia estruturam-se em três seções. A primeira delas apresenta as conceituações gerais sobre Eugenia e Eugenismo, enfatizando-se o discurso científico aliado a construção da soberania nacional de um Estado-Racialista. Se atualmente a compreensão das raças de um ponto de vista biológico não se sustenta, há 100 anos as diferenças fenotípicas eram associadas à atributos morais. Por sua vez, a segunda seção traz alguns elementos narrativos presentes ao longo dos números analisados. Através da ideia de "higiene racial”, os eugenistas propunham programas curriculares de educação eugênica em que o Ensino de Biologia (especificamente a Genética) se apresentava como imprescindível para o letramento científico da sociedade brasileira. A terceira seção traz um dos temas que mais aparecem na publicação aqui analisada: o incentivo a Educação Sexual (associada a seleção de traços raciais "desejáveis") percebida enquanto uma estratégia necessária para o progresso da nação. Nessa seção encontraremos as recomendações do estudo da hereditariedade antes do casamento e o incentivo de ações de esterilização como medida para eliminar a reprodução de traços indesejáveis, muitos deles associados a "tipos raciais".

Os resultados aqui reunidos colaboram para a Educação em Ciências a partir do momento no qual, através de uma perspectiva associada entre História, Filosofia e Sociologia, podemos compreender um fragmento da história educacional e dos usos do conhecimento científico na sociedade brasileira no início do século XX. Tal compreensão tem como premissa o reconhecimento das relações étnico-raciais e os processos de racialização fundamentados em uma linguagem científica, situando, sobretudo, as implicações sociais advindas dos usos deliberadamente relacionados à necropolítica. 


\section{Percurso metodológico e referenciais teóricos para a análise do Boletim de Eugenia}

O Boletim de Eugenia, idealizado pelo médico Renato Kehl ${ }^{1}$, possuía sua sede na cidade do Rio de Janeiro (à época centro administrativo e político do Brasil), posteriormente transferida para a cidade de Piracicaba (estado de São Paulo). Inicialmente uma publicação mensal (nos dois últimos anos a periodicidade foi trimestral), o Boletim de Eugenia era composto de diferentes seções temáticas. No Boletim eram veiculadas divulgações de livros escritos por membros das Sociedades Eugênicas, comunicações de pesquisas (com temas que abarcavam questões sobre educação, psicologia, hereditariedade, zoologia e botânica) e notícias pontuais (traduções de pequenos comunicados veiculados em outras publicações estrangeiras, convites para os Concursos de Eugenia, listas das sociedades eugênicas existentes em outros países, acontecimentos políticos, opiniões e até mesmo pequenas crônicas).

Inicialmente com tiragem de 1.000 exemplares e distribuição gratuita, a assinatura anual do Boletim passou a custar dez mil réis (o preço da assinatura anual subiu a cada ano, sendo este o preço da assinatura no ano de 1933). Seu público leitor era constituído por médicos, farmacêuticos, geneticistas, zoólogos, antropólogos, botânicos, agrônomos, diretores de museus científicos, inspetores de serviço sanitário, professores, literatos (a própria vinculação de Monteiro Lobato à Sociedade Eugênica de São Paulo nos demonstra essa capilaridade entre diversas áreas), políticos, mas também uma elite intelectual branca (ou que se esforçava em construir seu processo de racialização mais próximo da brancura europeia). Por esses espaços de produção científica (a exemplo das Sociedades Eugênicas) serem majoritariamente ocupados por pessoas de classes econômicas mais abastadas, não há como desconsiderar uma associação entre raça e classe (sem se esquecer de gênero, uma vez que quem produzia os textos publicados no Boletim de Eugenia eram majoritariamente homens).

Neste artigo foram analisados os 42 números do Boletim de Eugenia (Figura 1), publicados entre os anos de 1929 a 1933, e disponíveis no site da Hemeroteca Digital².

1 É importante destacar a atuação do Dr. Renato Kehl na promoção das ideias eugênicas no Brasil através de campanhas educativas e livros direcionados a pais, mães e educadores de forma geral, como as obras "Fada Hygia", "Bíblia da Saúde", "Pais, Médicos e Mestres" e "Educação Moral". Para maiores informações indica-se aqui o trabalho de Bonfim (2019).

2 Disponível em http://hemerotecadigital.bn.br/acervo-digital/Boletim-de-Eugenia/159808 


\section{BObETIII DE EUGEחÍh \\ SEPARATA DA "M E D I C A M E N T A" \\ REVISTA PARA MEDICOS E P H R M CEUTICOS}

\begin{tabular}{|c|c|c|}
\hline $\begin{array}{l}\text { PUBLICACXo OFFICIAL DA } \\
\text { COs. CENTR. BRAS. DE EUGENia } \\
\text { Assig. annual do Boletim avulso } 5 \$ 000 \\
\text { Caixa Postal } 2926 \text { - Hio de Janeiro - Brasll }\end{array}$ & $\begin{array}{l}\text { SETEMBRO DE } 1931 \\
\begin{array}{ll}\text { NNO III } & \text { N. } 33\end{array}\end{array}$ & $\begin{array}{c}\text { DIRECCXO E REDACCXO } \\
\text { D R. R EN A T O K E H L } \\
\text { R. Smith Vasconcellos, } 68 \text { (Aguas Ferreas) } \\
\text { Caixa Postal } 2926 \text { - Rio de Janeiro }\end{array}$ \\
\hline
\end{tabular}

Para guiar a análise dessas publicações, parto da premissa contida na noção de Necropolítica proposta por Mbembe (2016). Para o referido autor, há determinadas configurações políticas que definem aqueles indivíduos que possuem o direito de existir, ditando os que irão viver e os que devem morrer. Com o estabelecimento da noção ficcional de um inimigo que ameaça a soberania nacional, nas ações da necropolítica, teríamos "a percepção da existência do outro como um atentado contra minha vida, como uma ameaça mortal ou perigo absoluto, cuja eliminação biofísica reforçaria o potencial para minhas vida e segurança" (Mbembe, 2016, p. 129). Conforme veremos, esse inimigo ficcional é criado e representacionalmente associado a população negra e as consideradas miscigenadas, sendo a perspectiva antagônica dos sujeitos brancos brasileiros. A racialização do branco brasileiro passa por processos diferentes do norte europeu, uma vez que a branquitude aqui instituída buscou adequações de um racismo científico em uma sociedade na qual a descendência inter-racial está presente.

Alguns questionamentos feitos pela Schuchman (2012), em relação a construção da branquitude e a manutenção das suas relações de poder, podem nos interessar para o presente artigo. Para a autora, "quais os significados da branquitude em nossa cultura? De que forma ela se caracteriza? Quais as identificações em semelhanças e diferenças que os sujeitos brancos constroem com a branquitude? Quais os processos em que a raça opera na constituição dos sujeitos como brancos? Como a própria ideia de raça e os valores da branquitude diferenciam e hierarquizam internamente o grupo de brancos em nossa sociedade?" (Schuchman, 2012, p. 15).

Se através da análise dos diversos exemplares do Boletim de Eugenia busco perceber a consolidação de uma narrativa racista fundamentada em um discurso científico, é imprescindível reconhecer que a branquitude implica um sistema de privilégios estruturais para as pessoas consideradas brancas. Logo, há relações assimétricas de poder causadoras de opressões. Dado o caráter estrutural do racismo, uma pesquisa educacional que através da História da Ciência (com ênfase na Biologia) busque perceber elementos que sustentam relações de opressão no plano do discurso científico deve, necessariamente, se entrelaçar a outras categorias analíticas e referenciais teóricos vindos, por exemplo, das chamadas Ciências Humanas. 
De posse dessas duas categorias analíticas (Necropolítica e Branquitude), metodologicamente para a análise das 42 publicações, foram seguidas as recomendações contidas na "Análise Textual Discursiva" (Moraes, 2003). Há três etapas indicadas por Moraes (2003) em relação ao ciclo de análises textuais, sendo eles a (1) desconstrução do corpus textual, (2) a emergência de novos significados e (3) a comunicação das interpretações resultantes. Um corpus textual tem múltiplos significados e o ciclo de análise proposta por esta metodologia visa elaborar sentidos simbólicos. Ao desconstruir os textos presentes no Boletim de Eugenia, busquei aspectos que estariam ligados à necropolítica e a constituição da branquitude a partir do discurso científico. Das 42 publicações do Boletim de Eugenia selecionei 63 textos que compuseram uma amostra inicial. Conforme indico mais adiante, muitos desses textos possuíam temas idênticos. Destaque deve ser dado que os 42 números do Boletim de Eugenia possuem elementos discursivos-textuais que se coadunam com a delimitação de uma noção ficcional de inimigo, cuja existência deveria ser combatida através da promoção da ciência eugênica.

Também é importante ressaltar que mesmo com a seleção dos textos para esta análise, em outras partes do Boletim de Eugenia, a racialização sempre esteve presente, pelo menos em elementos que a sustentam. Posso citar como exemplos os artigos veiculados em alguns números do Boletim de Eugenia que transmitiam descobertas sobre o melhoramento genético de plantas alimentícias ou flores ornamentais. Mesmo que esses trabalhos tenham sido escritos por agrônomos, tais pesquisas eram utilizadas como exemplos e relações para processos maiores que deveriam ser aplicados aos seres humanos. Os eugenistas partiam da premissa de que se caracteres morfológicos poderiam ser selecionados em plantas, da mesma forma poderiam ser selecionados em seres humanos. No caso relacionado aos humanos, havia a percepção de que caracteres morfológicos correspondiam à atributos morais.

Em um primeiro momento da análise, me ative às construções textuais que enfatizavam as relações entre pessoas brancas e não-brancas. Contudo, com o acúmulo das leituras dos números e dos processos de apreensão das unidades fundamentais do corpus textual, outros sentidos e significados que não estavam latentes puderam emergir. Assim ocorreu, por exemplo, com as análises das medidas sobre "Educação Sexual" e de como tal prática, no Boletim de Eugenia, se referiam às relações inter-raciais (mesmo que isto não fosse enfatizado em alguns casos). Como indicado por Moraes (2003), o ciclo de análise discursiva pode usufruir de um método que, para além do dedutivo e indutivo, seja intuitivo, constituindo-se por quem pesquisa a partir da impregnação nos dados relacionados aos fenômenos. Esse movimento metodológico representa aprendizagens auto-organizadas geradas por um envolvimento intenso com o fenômeno que se investiga.

Dessa forma, as informações contidas nos números do Boletim de Eugenia foram relacionadas, buscando-se, na interpretação dos textos, o estabelecimento de relações e a captação dos seus significados. Se o ato de "interpretar é construir novos sentidos e compreensões afastando-se do imediato e exercitando uma abstração em relação às 
formas mais imediatas de leitura de significados de um conjunto de textos" (Moraes, 2003, p. 204), as categorias geradas a partir das leituras dos exemplares do Boletim de Eugenia e postas em análise foram interpretadas buscando-se identificar os elementos de um discurso científico que configurou o lugar do sujeito branco. Todavia, cabe ressaltar que "as descrições, as interpretações e as teorizações, expressas como resultados da análise, não se encontram nos textos para serem descobertas, mas são resultado de um esforço de construção intenso e rigoroso do pesquisador" (Moraes, 2003, p. 206). Os processos de teorização resultantes reforçam agendas de pesquisas educacionais em Ciências e Biologia que não se atenham somente às disciplinas diretamente correlatas (a exemplo da Genética), mas que percorrem premissas da História, Sociologia e Antropologia.

A tabela a seguir exemplifica alguns textos veiculados no Boletim de Eugenia que foram selecionados para a análise e interpretação (Figura 2). As informações referentes a autoria (titulação e/ou lugar de origem) foram retiradas literalmente da forma que apareciam nas publicações, salvo aquelas que não possuíam indicativos e assim explicitadas na tabela. Dada a extensão das informações, caso elas fossem ser colocadas na íntegra, optei por apresentar uma síntese desses textos. Como dito anteriormente, isso também se deve ao fato de que os mesmos temas contidos em alguns desses números foram retomados em mais de um exemplar do Boletim de Eugenia, geralmente por autores diferentes (a exemplo de "Eugenia e Eugenismo"). Portanto, a tabela não representa a totalidade dos textos sobre os quais a perspectiva aqui analisada se apresentou, consistindo em um recorte ilustrativo para a situação.

Figura 2. Alguns textos veiculados no Boletim de Eugenia entre os anos de 1929 a 1933 e tomados como corpus de análise textual (continua)

\begin{tabular}{|l|l|c|}
\hline Título & Autoria & No / Ano \\
\hline Eugenia e Patriotismo & Prof John Edgar (Universidade de St. Andrews) & $3 / 1929$ \\
\hline Ensino de Biologia & Leonardo Darwin & 6 e $7 / 1929$ \\
\hline Os fundamentos científicos da Eugenia & Luis Huerta (de Madrid) & $8 / 1929$ \\
\hline O Brasil e a raça & João do Norte (da Academia Brasileira de Letras) & $8 / 1929$ \\
\hline Educação e Eugenia & Dr. Renato Kehl & $9 / 1929$ \\
\hline A seleção dos bem-dotados & Prof. O. Decroly & $10 / 1929$ \\
\hline Eugenia e Eugenismo & Belisario Penna & $10 / 1929$ \\
\hline $\begin{array}{l}\text { O problema imigratório e o futuro do } \\
\text { Brasil }\end{array}$ & $\begin{array}{l}\text { Resumo da conferência do Sr. Antonio de Queiroz } \\
\text { Telles, no Rotary Club de S.Paulo }\end{array}$ & $11 / 1929$ \\
\hline $\begin{array}{l}\text { O Ensino da Genética nas escolas } \\
\text { primarias }\end{array}$ & Autoria não informada & $11 / 1929$ \\
\hline $\begin{array}{l}\text { Esterilização para aperfeiçoamento } \\
\text { humano }\end{array}$ & Renato Kehl & $12 / 1929$ \\
\hline $\begin{array}{l}\text { O atestado médico pré-nupcial } \\
\text { Os programas de ensino e a Genética }\end{array}$ & $\begin{array}{l}\text { Prof Dr. Victor Delfino (da Acad. de Medicina de } \\
\text { Madrid, Rio de Janeiro e Lima) } \\
\text { Pharmacia e de Odontologia Washington Luis) }\end{array}$ & $12 / 1929$ \\
\hline
\end{tabular}


Figura 2. Alguns textos veiculados no Boletim de Eugenia entre os anos de 1929 a 1933 e tomados como corpus de análise textual (continuação)

\begin{tabular}{|c|c|c|}
\hline Título & Autoria & $\mathrm{N}^{\circ} /$ Ano \\
\hline $\begin{array}{l}\text { Biologia racial (perspectivas e pontos de } \\
\text { vistas eugênicos) }\end{array}$ & Prof. Dr. H. Lundborg & 14 / 1930 \\
\hline A Biologia servindo ao Direito & Almeida Magalhães & $14 / 1930$ \\
\hline $\begin{array}{l}\text { A eugenia como ciência e como ideal } \\
\text { social }\end{array}$ & W. Schraenen & $15 / 1930$ \\
\hline Crescei e multiplicai-vos & Renato Kehl & $18 / 1930$ \\
\hline Não basta gritar - Viva o Brasil! & Autoria não informada & $19 / 1930$ \\
\hline O lar e a educação sexual das crianças & E.R. & $22 / 1930$ \\
\hline $\begin{array}{l}\text { O problema da educação sexual } \\
\text { (importância eugênica da educação } \\
\text { sexual - falsa compreensão e falsos } \\
\text { preconceitos - como, quando e por quem } \\
\text { deve ela ser ministrada) }\end{array}$ & Renato Kehl & $24 / 1930$ \\
\hline Educação Sexual & Dra. Paulina Luisi (de Montevidéu) & $24 / 1930$ \\
\hline Poderemos ser melhores? & Prof. Octavio Domingues & $26 / 1931$ \\
\hline A eugenia e a reforma do ensino & $\begin{array}{l}\text { Trecho da exposição de motivos apresentada } \\
\text { ao Chefe do Governo Provisorio pelo Exmo Sr. } \\
\text { Dr. Francisco de Campos, illustre Ministro da } \\
\text { Educação e Saude Publica }\end{array}$ & $28 / 1931$ \\
\hline O eugenismo das elites & Oliveira Vianna & $29 / 1931$ \\
\hline Cruzamento do branco com o preto & $\begin{array}{l}\text { Prof. Luiz L. Silva (da Faculdade de Pharmacia e } \\
\text { Odontologia de Santos) }\end{array}$ & $30 / 1931$ \\
\hline $\begin{array}{l}\text { "Birth-control", esterilização e pena de } \\
\text { morte }\end{array}$ & Prof. Octavio Domingues & $30 / 1931$ \\
\hline $\begin{array}{l}\text { O ensino da eugenia nas escolas } \\
\text { secundárias }\end{array}$ & Renato Kehl & $30 / 1931$ \\
\hline A campanha da Eugenia no Brasil & Renato Kehl & $33 / 1931$ \\
\hline Cruzamento de raças & $\begin{array}{l}\text { Prof. Herman Lundborg (Diretor do Instituto de } \\
\text { Biologia Racial de Upsala) }\end{array}$ & $34 / 1931$ \\
\hline $\begin{array}{l}\text { O que pode resultar do casamento entre o } \\
\text { branco e o preto }\end{array}$ & $\begin{array}{l}\text { Prof. S. de Toledo Piza Junior (da Com.Central Br. } \\
\text { de Eugenia) }\end{array}$ & 37 / 1932 \\
\hline $\begin{array}{l}\text { O casamento do branco com o preto a luz } \\
\text { da Biologia }\end{array}$ & $\begin{array}{l}\text { Prof. S. de Toledo Piza Junior (da Com.Central Br. } \\
\text { de Eugenia) }\end{array}$ & $38 / 1932$ \\
\hline $\begin{array}{l}\text { A hereditariedade da cor da pele no } \\
\text { casamento branco-preto }\end{array}$ & Prof. S. de Toledo Piza Junior & $39 / 1932$ \\
\hline $\begin{array}{l}\text { Limalhas de um Eugenista, a Eugenia e os } \\
\text { recentes programas políticos }\end{array}$ & $\begin{array}{l}\text { Prof. Octavio Domingues (da Eugenics Society de } \\
\text { Londres }\end{array}$ & $39 / 1932$ \\
\hline $\begin{array}{l}\text { Limalhas de um Eugenista, a Educação } \\
\text { sob o ponto de vista eugênico }\end{array}$ & $\begin{array}{l}\text { Prof. Octavio Domingues (da Eugenics Society de } \\
\text { Londres }\end{array}$ & $40 / 1932$ \\
\hline $\begin{array}{l}\text { Darwin, uma das maiores figuras do } \\
\text { século } 19\end{array}$ & Archibald Henderson & $40 / 1932$ \\
\hline Um programa para a Eugenia & Prof. S. de Toledo Piza Junior & $42 / 1933$ \\
\hline
\end{tabular}




\section{Eugenia e Eugenismo: a "higiene da raça"}

Ao passar dos números publicados do Boletim, através da análise empreendida pode ser percebida uma preocupação em se apresentar a finalidade da Eugenia e o seu campo conceitual. As definições iniciais, como as que estão contidas no primeiro número do ano de 1929, dão conta da Eugenia como uma ciência que tem por finalidade "melhorar e proteger a espécie, pelo melhoramento e pela protecção das bôas sementes e de seus portadores".

Em outros volumes, a Eugenia é apresentada tanto como uma "ciência e arte" (em artigo de Luis Huerta, no Boletim de número 8, no ano de 1929), mas também uma "sciencia-religiao" (na opinião de Renato Kehl, em artigo publicado no número 30 do ano de 1931). Para Luis Huerta, os gregos foram os primeiros a aplicarem o eugenismo, mas a Eugenia, enquanto Ciência Biológica, foi fruto da criação de Francis Galton ${ }^{3}$. No Brasil, o movimento eugênico (composto por médicos, higienistas, antropólogos, jornalistas, educadores, juristas) se constituiu como um campo complexo e fragmentado (Fiuza, 2016). Recorrentemente a Eugenia foi apresentada como uma "higiene racial", associando-a a questões sanitárias, de medicina social e de criminalística.

O conceito de raça é intensamente debatido no campo dos estudos acadêmicos, observando inevitavelmente suas consequências políticas. Se contemporaneamente a concepção biológica de raça não mais se sustenta tal qual em séculos passados, nem por isso devemos deixar de considerar a força do conceito em suas representações sociais, uma vez que as formas de dominação e segregação são estruturadas a partir dessas concepções. Não caberia aqui uma apresentação pormenorizada sobre a constituição histórica desse conceito, ao qual a/o leitor/a encontrará inúmeros trabalhos sobre isso. Neste trabalho, para guiar a análise do Boletim de Eugenia e a sua proposta racialista, destaco dois referenciais que podem nos ajudar.

De acordo com Guimarães (2009, p. 31), o conceito de raça faz sentido no âmbito de uma ideologia a qual o referido autor chama de "racialismo". Trata-se de um conceito "que ajude o pesquisador a compreender certas ações subjetivamente intencionadas, ou o sentido subjetivo que orienta certas ações sociais". Por sua vez, Sanchez-Arteaga et al. (2015) propõem a noção de "processos de alterização" em relação aos critérios científicos históricos das Ciências Naturais (especialmente a Biologia e Biomedicina) que estabelecem as fronteiras entre os diferentes grupos humanos (separando, por exemplo, os aptos dos inaptos, sadios de doentes, primitivos de evoluídos), delimitando e determinando as diferenças de poder e, consequentemente, das possibilidades de ações. Esses processos de alterização que conduzem à inferiorização e exclusão, permeiam discursos e práticas científicas mesmo quando os fatores não são facilmente discerníveis.

3 Francis Galton nasceu no ano de 1822 e faleceu em 1911. Era primo de Charles Darwin e a Galton se atribui a criação do conceito de Eugenia. Dentre suas obras destacam-se "Hereditary Genius" (1869) e "Inquiries into Human Faculty and its development" (1883). 
O que aqui também nos importa perceber é que raça não é uma categoria intrínseca (o que seria uma realidade biológica). Raça, como aqui é compreendida, só tem sentido no âmbito das relações sociais, do encontro com o que é percebido enquanto diferença e de como a mesma é representada nas relações assimétricas de poder entre os indivíduos e seus grupos sociais. Não é associada exclusivamente a questão da coloração da pele (apesar desta ser um dos principais critérios adotados para a opressão), pois se assim fosse, não teríamos o registro historiográfico do holocausto judeu nas campanhas eugenistas do Partido Nazista e/ou as difíceis adequações do racismo científico no Brasil (conforme veremos adiante).

Ao se discutir o Boletim de Eugenia em seus processos de racialização a partir das estratégias de divulgação e educação científica, é imprescindível perceber que a classificação e representações sobre "o outro" também nos diz muito sobre quem estabelece a classificação. Na relação entre observador e observado, Maturana (2014) nos orienta a prestar atenção sobre quem estabelece o discurso pelo qual os mecanismos de explicação e reformulações da experiência terão legitimidade dentro dos grupos que reconhecem a linguagem comunicativa utilizada.

Tomando como exemplo os lugares dos indivíduos racializados enquanto pessoas brancas, apenas a coloração da pele, a depender da situação e circunstância histórica, podem apresentar imensas variações nas relações sociais. Para focarmos na realidade brasileira, indivíduos de cor branca na região Nordeste, ao chegarem na região Sudeste, podem ser considerados "mestiços menos brancos". Em contrapartida, indivíduos considerados brancos no Sudeste provavelmente serão categorizados enquanto "mestiços latinos" em países do Norte (Estados Unidos da América e outros do continente europeu $)^{4}$. O que parece ser inegável, a partir do campo dos estudos das relações étnico-raciais e da historiografia, é que os grupos sociais racializados sempre coincidiam com processos de formação dos Estados enquanto Nações. Esse fato nos demonstra o esforço de imposição, por parte de certos grupos, no estabelecimento de seus símbolos, línguas, costumes, entre outros aspectos que visam a constituição de uma suposta identidade nacional hegemônica e patriótica.

No terceiro número publicado no ano de 1929, em artigo intitulado "Eugenia e Patriotismo", de autoria do Prof. John Edgar, da Universidade de St. Andrews, lemos a seguinte definição:

A Eugenia é fundamentalmente uma sciencia que estuda os factores que sob controle social poderão prejudicar ou beneficiar as qualidades raciais das futuras gerações, tanto physica como mentalmente. Como sciencia ella se dedica a investigação cuidadosa dos factos, assim como a chimica e a physiologia ou outra qualquer sciencia natural, e, partindo dos mesmos factos procurar, por um meio

4 Um bom exemplo dessa situação pode ser encontrado na obra cinematográfica "Bacurau”, dos diretores Kleber Mendonça Filho e Juliano Dornelles. O casal de brancos do sudeste, ao chegar no vilarejo de Bacurau, desdenham da população nordestina ali residente enquanto na cena seguinte, ao chegarem em uma casa com "outras pessoas brancas", norte-americanas, é o casal que passa a ser desdenhado por serem considerados "menos brancos" e latinos. 
logico, formar os seus princípios. Sua aspiração máxima é a verdade. Ella não tem ligação com nenhum systema social ou econômico, cujo estudo e princípios podem inspira-la.

Ainda para o referido autor, "a grande e pratica missão do Eugenista, portanto, deve ser a creação e desenvolvimento de um novo patriotismo". De acordo com Bizzo (1995), havia uma preocupação dos propagandistas eugênicos em fazer coincidir os termos Raça e Nação, uma vez que o progresso de um implicaria na fortificação do outro. A aplicação da ciência eugênica, pautada no progresso da espécie humana, é na maioria das vezes incentivada por políticas nacionalistas (Fiuza, 2016). O quarto volume do Boletim de Eugenia lemos que a mesma tem por fim:

(...) cooperar para o augmento progressivo dos homens physica, psychica e moralmente sadios, para a diminuição paulatina do contingente dos fracos, doentes e degenerados, - concorrendo, desse modo, para a constituição de uma sociedade mais sã, mais moralizada, em summa, uma humanidade equilibrada, composta de indivíduos fortes e bellos, elementos de paz e de trabalho.

A sucessão dos números publicados e a necessidade de definições sobre a Eugenia/Eugenismo nos concede informações que demonstram o que passava a ser considerado, no Brasil, como a "proteção das boas sementes germinativas". "Boas sementes" eram aquelas provindas de indivíduos brancos, sem passagens criminosas, de classes econômicas mais favorecidas e que ocupavam posições de destaque social, sem vícios (jogatinas, álcool, tabagismo), qualquer outro tipo de traços considerados como degenerescência ou doença. Indicadores através dos quais a partir da compreensão da hereditariedade enquanto teoria biológica, fez com que os eugenistas buscassem os melhores elementos não somente nos indivíduos em si, mas em suas linhagens familiares (como tão bem predisposto nos Concursos de Eugenia).

Definir o que é a branquitude e quem ocupa os lugares de sujeitos brancos, implica o envolvimento de categorias sociológicas de etnia, cor e cultura, por exemplo, e dependem do país, região, interesses políticos e épocas de investigação (Schuchman, 2012). A partir dos diferentes significados compartilhados culturalmente, "ser branco e ocupar o lugar simbólico de branquitude não é algo estabelecido por questões apenas genéticas, mas sobretudo por posições e lugares sociais que os sujeitos ocupam" (Schuchman, 2012).

Tais práticas, para Bizzo (1995, p. 37), visavam não o progresso científico, mas a redefinição do conceito de cidadania, uma vez que "o paradoxo social-eugênico dependeu da concordância de intelectuais de todo tipo", cuja implementação conduziu a medidas políticas de interesse de segmentos restritos da sociedade. Em notícia veiculada no ano de 1930, propagandeava-se a necessidade de se estudar, pregar e praticar as leis ditadas pela Eugenia como forma de ser um bom cidadão que zela, eugenicamente, pelas futuras gerações de brasileiros (Figura 3). 
Figura 3. Trecho de notícia veiculada no Boletim de Eugenia no ano de 1930

\section{lião basta gritar: - Viva o Brasil! \\ E' preciso ser bom brasileiro, auxiliando, por todos os modos, o methoramento physico, psychico e moral dos nossos patricios. \\ E' preciso ser tambem um bom cidadão, zelando, eugenicamente, pelo futuro das ge- rações que povoarāo o Brasil de amanhã. \\ Eis por que devemos todos estudar, pre- gar e praticar as leis dictadas pela eugenia.}

O paradoxo social-eugênico indicado por Bizzo (1995) consiste na difícil aplicação de teorias criadas em outros lugares do mundo, cujas configurações sociais eram nitidamente diferentes das encontradas no Brasil. A população brasileira, como bem demonstravam os censos (apesar dos mesmos ocultarem a verdadeira identidade racial dos indivíduos), era majoritariamente negra, logo, como seria possível a aplicação de teorias científicas europeias, focadas nas pessoas brancas sem histórico de relações inter-raciais recentes? Como propor e aplicar na sociedade brasileira um pensamento científico no qual havia a afirmação de que o "cruzamento das raças" (entre os eugenistas eram esses os termos utilizados, conforme veremos mais adiante) conduzia a degenerescência da sociedade? Por isso as ideias eugênicas, para o referido autor, são indicadas como um paradoxo social. Se haviam pessoas críticas no Brasil à essa teoria, na qual sustentavam em seus argumentos justamente essa contradição, o pensamento eugênico em solo brasileiro teve que passar por flexibilizações para ser aceito pelas amplas camadas da sociedade.

Em praticamente todos os números do Boletim de Eugenia essa problemática não é levada em consideração, sendo que apenas no número 39 do ano de 1932, em artigo escrito pelo Prof. Octavio Domingues, temos uma inversão desse dilema:

Por ai parece haver uma vaga duvida a respeito da aplicação da eugenia entre nós brasileiros, sob o fundamento de que somos mestiços... e como tais não há como aplicar os princípios eugênicos na constituição da nossa raça. Mestiçamento de raças humanas não é sinônimo de degeneração. É antes origem e fonte de novos biotipos, entre os quais teremos aqueles capazes de uma adaptação melhor da nossa raça em formação é a grande promessa da eugenia no Brasil.

Esse simples parágrafo pode nos indicar os ataques que os eugenistas sofriam em sua teoria ao propagandearem medidas e ações cuja maior parte da sociedade brasileira seria excluída. Conforme veremos mais adiante, o mesmo Prof. Octavio Domingues, em outros números do Boletim, propõe medidas que poderiam nos indicar sua repulsa ao 
"mestiçamento de raças humanas".

Na seção a seguir, visualizaremos que entre os eugenistas havia uma preocupação em instituir a Eugenia enquanto um programa educativo nos estabelecimentos de ensino (apesar de que a própria publicação era um mecanismo de educação e divulgação científica). Isso se deve ao fato de que essas instituições educativas propiciam letramentos científicos vistos como necessários à compreensão da sociedade diante os conceitos e práticas científicas propostas para o chamado melhoramento racial. A seguir poderemos perceber melhor algumas justificativas e estratégias conduzidas para a inserção da Eugenia nos programas curriculares de ensino.

\section{Educação eugênica: o Ensino de Biologia}

No ano de 1929 (especificamente no Boletim de número 6-7) encontramos uma notícia atribuída a Leonardo Darwin, filho de Charles Darwin, recomendando a inclusão do Ensino de Biologia, apresentando como motivos o fato de que "o conhecimento dos maiores interesses nacionais está aliado à constituição biológica das gerações futuras":

O Ensino da Biologia para os homens políticos

Numa carta endereçada ao "Times", em nome da "Eugenics Society" da qual é presidente, Leonardo Darwin, filho do grande Charles, pede a introducção da biologia nos programmas escolares, porque o conhecimento do quanto os maiores interesses nacionaes estão alliados a constituição biológica das gerações futuras, diffundido entre as classes cultas, constitue a única salvaguarda verdadeira contra os perigos sociaes.

Está hoje universalmente reconhecido que as leis da herança têm vital importância, não só para o incremento e melhoramento dos productos da terra, como também para o desenvolvimento da vida humana. Darwin afirma em seguida que não unicamente os aspirantes a uma cathedra de apicultura devem possuir a adequada preparação scientifica, mas é de summa importância que todos quanto aspirem um posto eminente na politica nacional, na pratica ou nas colônias, possuam solidas noções das leis que governam a existência humana e a sua evolução (Extrahido da Folia Medica, 30-4-929).

No Boletim número 9, publicado no ano de 1929, em texto sobre Educação e Eugenia, escrito por Renato Kehl, encontra-se a afirmação do citado autor de "quem é bom já nasce feito". Nesse texto considera-se que a humanidade é composta por três qualidades de gente: "gente innata e intrinsecamente humana, gente domesticável e gente doente ou indomável". A seguir transcrevo um trecho que exemplifica a percepção da aprendizagem pela educação eugênica:

Dentro deste critério, terá a pedagogia moderna de encarar os seus problemas do mesmo modo por que são tidos na medicina os problemas therapeuticos: considerar o doente antes da doença, e, do mesmo modo, considerar o educando antes da educação que se lhe pretende dar (...) 
Do mesmo modo, em pedagogia, éindispensável conhecer, não só a personalidade, como também a individualidade, antes de considerar o paciente, que se vae educar. Os methodos educativos modernos baseam-se nas indicações fornecidas pela psychologia. Isto não nos parece sufficiente. Torna-se necessário também os seus caracteres somáticos e constitucionaes. A individualidade, como a personalidade, - o modo de sentir, de agir, as tendências, os costumes, a capacidade intellectual ou physica são reflexos desses caracteres innatos.

Eis, porque, a educação esbarra, impotente, em muitos casos, não conseguindo domesticar um indocil, cuja constituição é resultante de um processo hereditário irremovível.

Quem é bom já nasce feito!...

A importância da Educação, para os eugenistas, era pontuada desde o primeiro número do Boletim, no qual lemos que a educação teria uma função civilizadora. É inegável que toda prática educativa possui uma função civilizadora, caso percebamos essa função enquanto processo de socialização histórica de determinados indivíduos em um sentimento de coletividade. A questão implícita aqui é a de qual processo civilizatório se faz referência.

No Boletim de Eugenia temos tanto o incentivo à Educação percebida de uma forma mais ampla, através de campanhas e da divulgação das atividades das sociedades eugênicas, mas também do ensino escolarizado, tanto nas escolas primárias quanto nas secundárias, Escolas de Agronomia, Faculdades de Medicina, entre outras. Incentivavase o ensino de Genética, visto que essa área do conhecimento era fundamental para a compreensão dos heredogramas, das transmissões de caracteres e de outros princípios científicos a partir dos quais a Eugenia sistematizava suas interpretações. No Boletim número 13, do ano de 1930, em artigo intitulado "Os programmas de ensino e a Genetica", de autoria do Prof. Octavio Domingues (da Escola Superior de Agricultura "Luiz de Queiroz" e da Faculdade de Pharmacia e de Odontologia "Washington Luis"), lemos a seguinte preocupação do autor:

Sobre hereditariedade, o que há é uma somma grande de preconceitos, e, como preconceitos que são, formam uma espécie de couraça tornando a nossa gente pouco porosa as verdades da Eugenia. Quem por ahi não sabe da influencia da lua, de um eclipse, de uma chave trazida ao cós etc. etc., sobre o filho que a mulher traz ao ventre? E o susto que um macaco pregou na gestante? Não deu motivo a um descendente de formas simiescas? Como tirar da nossa população essas crendices, verdadeiros dogmas que a tradição oral conserva e solidifica? Só há um meio: levar a Genetica geral para os nossos programmas de ensino.

Curiosamente boa parte desse incentivo ao ensino da Genética se detinha ao cultivo de plantas ornamentais, utilizando esse recurso como ferramenta didática para a compreensão da transmissão de caracteres desejados. O professor Octavio Domingues, 
no referido Boletim publicado em 1930, comenta sobre essa facilidade em se demonstrar a necessidade da ciência eugênica:

Demais, se é necessário que o conhecimento da Genetica se inicie na Escola primaria, como faz sentir o Prof. A. J. Sampaio, claro será que a professora ou o professor, ao sahir da Normal, deve levar uma bagagem de biologia capaz de tornal-o hábil para despertar na criança o interesse pelos fenômenos da hereditariedade. Aliás, esse interesse não é difícil de despertar, desde que se mostre como a belleza ou a feiura da flor, de hoje, passará as flores da geração que della se originar.

Em 1931, no Boletim número 30, Renato Kehl escreve um artigo sobre "O ensino da eugenia nas escolas secundárias". Nesse trabalho, o citado autor busca estabelecer, de modo sintético "o esboço de um programma didactico exequível como parte da cadeira de historia natural ou, melhor, isoladamente, na ultima ou na penúltima serie do curso gymnasial”. A seguir apresento transcrição do referido esboço programático:

1- Eugenia - definição e finalidades

2- Historico - os precursores do eugenismo, o seu fundador, progresso realizado após a fundação.

3- Relações da Eugenia com a hygiene e a medicina social.

4- Fundamentos da Eugenia - doutrina de Lamarck (sobre a acção evolutiva do meio), de Darwin (sobre a seleção natural), de Weissmann (sobre o plasma germinativo), de Mendel (sobre a hybridação), de Semon (sobre a "mneme") de Nussbaum (sobre a identidade do plasma).

5- Principios eugênicos - lei biogenética, lei da conservação do typo ancestral, lei da evolução orgânica, leis da hereditariedade, lei do atavismo, lei de Galton, lei do isochromismo.

6- Methodo eugênico - estudos sobre as questões da hereditariedade e sobre a propaganda para despertar o interesse popular pelas medidas de defesa e protecção sociaes contra as taras e vícios degenerados.

7- Meios propostos: regulamentação eugênica do casamento, propaganda contra os factores dysgenizantes, puericultura, conceitos e preceitos eugênicos.

8- A responsabilidade e os deveres individuaes em face da espécie.

Renato Kehl encerra o referido artigo concluindo que "A educação eugênica é imprescindível para o progresso biológico, moral e social dos homens, devendo figurar, obrigatoriamente, no programma dos cursos gymnasiaes e normaes, como matéria a parte ou, não sendo possível, como parte da história natural ou da hygiene”.

Como dito anteriormente, algo com o qual os eugenistas sempre se defrontavam era a problematização da aplicação das ideias eugênicas na sociedade brasileira, uma vez que as premissas da Eugenia condenavam uma sociedade majoritariamente mestiça, negra e indígena. Vejamos por exemplo a opinião do Prof. Octavio Domingues em artigo intitulado "Poderemos ser melhores?", no ano de 1931, número 26: 
Poderemos ser felizes aqui? Talvez, si formos bons. Disto deve ressaltar a anciedade do homem em se fazer melhor, para ser feliz. Mas, poderemos ser melhores do que somos? Donde vem a nossa imperfeição? Ainda hontem commentando um livro de Dewey, o incomparável philosopho da educação, affirmava convicto que todos os males em geral tem sua origem em duas causas: erros na concepção biológica da criança, erros na educação della.

Mais adiante nesse mesmo artigo, o autor afirma: "Melhores geneticamente, melhores socialmente educados". Presumia-se que o paulatino melhoramento genético ocasionaria melhores condições de aprendizagem e, a partir disso, com as supostas limitações da sociedade brasileira, a mesma poderia ser considerada melhor. Como dito no início deste trabalho, campanhas eugenistas eram realizadas no Brasil e com o passar dos anos, alguns partidos políticos emitiam seu apoio. Objeto central dessas campanhas era o caráter educativo, tanto da população que não se encontrava mais nas escolas (ou sequer as tinhas acessado), mas principalmente da inclusão do Ensino de Biologia, da Genética e de conhecimentos sobre teorias da hereditariedade nos programas escolares primários e secundários (Figura 4).

Com todos os esforços ao longo dos anos, os eugenistas vão identificar, na sociedade brasileira, o analfabetismo como uma das causas que impedem a compreensão dos elementos importantes para a ciência eugênica. No ano de 1933, no boletim número 42, o Prof. S. de Toledo Piza Junior, ao propor um programa de eugenia, contempla a questão do analfabetismo e do ensino de Genética nas escolas secundárias e superiores, conforme notamos em dois trechos abaixo transcritos:

A semente eugênica, entendo, só poderá medrar em terreno fértil, adrede preparado. Esse terreno não existe absolutamente numa terra em que a quase totalidade da população não sabe ler e o restante, que sabe, não lê. Deante essa verdade nua e crua, cuide a Eugenia, antes de tudo, de preparar o homem. O futuro da Eugenia está em grande parte na cartilha da escola primaria. Si é bem verdade que as escolas secundarias e superiores formam técnicos, profissionais, cientistas, a escola primaria forma o cidadão. E o cidadão, isto é, o individuo de cultura ou não, que aprendeu a conhecer a grandeza e as possibilidades de sua terra, que se habituou a respeitar os seus concidadãos, que se acostumou a crer na palavra do mestre, e sobretudo, do individuo que aprendeu na escola a cumprir as leis que vigoram no seu paiz e amar a pátria e a família depende em primeira linha o sucesso.

O ensino da genética e da Eugenia nas escolas secundarias e superiores teria por objetivo preparar um mestre melhor para o adolescente e médicos e jurisconsultos mais habilitados para organizar a segunda parte de um programa (...). Urge, porém, instruir, educar, escrever, falar, ensinar, divulgar... Disso só bem advirá. O resto de um programa para a Eugenia virá oportunamente. 
Figura 4. Tradução de trechos da obra "Hygiene des Races", publicado no Boletim número 33, do ano de 1931

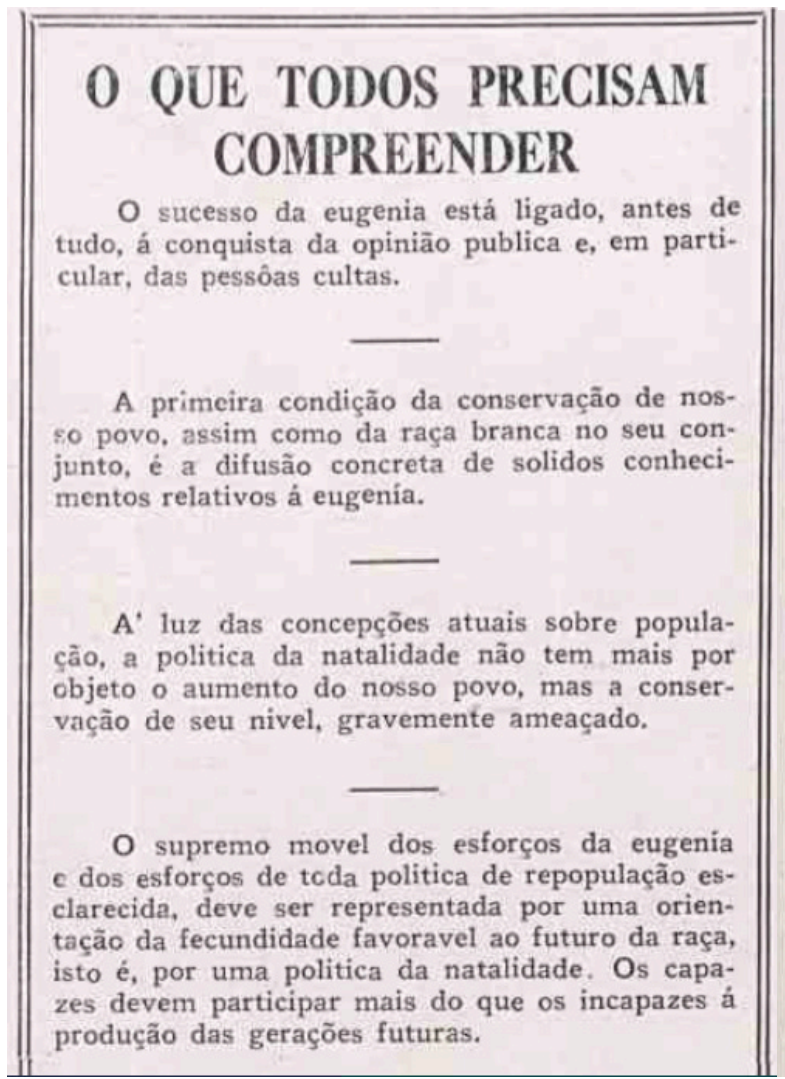

Tcdo homem razoavel deveria almejar que seus filhos não saissem da escola apenas com a bagagem correspondente a uma "bôa educação", mas com uma concepção clara das leis naturais C dos processos que dominam a vida individual e social. Possa o corpo docente das escolas, do qual uma parte fez á eugenia um acolhimento entusiastico, substituir a pouco e pouco as materias sem valor dos programas escolares por encinamentos que tenham relação $\mathrm{com}$ a conduta da vida, afim de que se torne verdadeira a velha frase: não nos intruimos para a escola, mas para a vida".

De todos os conhecimentos, cujo conjunto constitue as ciencias naturais, nenhum tem pela vicia da familia, da raça e do Estado, uma significação mais profunda do que as teorias da hereditariedade e da seleção e a sua applicação pratica, A EUGENIA OU HIGIENE DA RAÇA.

A introdução dum ensino de biologia geral c de eugenia nos liceus, ginasios, colegios e escclas; a creação de cadeiras para estas ciencias nas universidades; a anexação destas teorias aos conhecimentos que fazem o objeto de todos os exames (compreendendo-se os exames de direito e de econcmia política) constitue a reveindicação mais premente da eugenia.

Trechos da obra "Hygiene des Races", Prof. Dr. H. Werner Siemens da Universidade de Muenchen).

Por fim, cabe frisar que se em 1931 foi criada a Comissão Central Brasileira de Eugenia, no ano de 1934 temos a promulgação de uma Constituição Brasileira na qual havia a menção explícita em propiciar uma educação eugênica. Textos explicando as supostas vantagens da Eugenia estiveram presentes nos livros de formação de professores por muitos anos e que somado à escassez de materiais voltados para tais fins, supõe-se que grande parte dos docentes, em algum momento, chegaram a ter algum desses livros (Gioppo, 1996).

Em sua tese de doutoramento, Priscila Silva (2015) analisa as correspondências entre Renato Kehl e diretores das faculdades que posteriormente foram agrupadas no projeto da Universidade de São Paulo (USP). O projeto USP foi concebido em 1934, mesmo período histórico citado acima. Construída sobre a promessa de uma instituição com a missão de "melhoramento social", a referida autora demonstra que ideias eugênicas estiveram presentes nos objetivos educacionais da universidade (Silva, 2015). Raça, Nação e Ciência (a exemplo das instituições) se entrelaçavam e politicamente se estruturavam na sociedade brasileira do início do século XX.

Dessa forma, no Brasil a Eugenia assumiu uma prática de discurso científico que ao propor o melhoramento racial da população brasileira, encontrou nas instituições de educação um importante espaço para a consolidação de uma narrativa de soberania 
nacional. A formação do que era visto como a "melhor constituição racial da nação brasileira", no discurso eugênico, pode ter fundamentado o processo de formação de professores e concepções sobre os processos de ensino-aprendizagem nas escolas. Não temos como desconsiderar que paralela à preocupação por instituir um programa educativo nas escolas, a formação desses professores e professoras para lidar com a ciência eugênica também passava a ser incentivada. A análise dos textos retirados dos números do Boletim de Eugenia, revela que ao professor e professora se atribuía um "dever patriótico" (ao relacionarmos Eugenia com a construção da Nação e soberania nacional) para identificar os indivíduos considerados portadores de características físicas e morais desejáveis, quando ainda estivessem nas escolas. A depender se professor (homem) ou professora (mulher), especificidades pedagógicas ainda eram atribuídas, a citar a questão da educação sexual no início da adolescência sendo de competência das professoras, por se considerar que as mulheres seriam mais amorosas e atenciosas.

A ciência eugênica se constitui em uma técnica da Necropolítica (Mbembe, 2016) ao produzir a diferença como elemento que deve ser segregado e excluído. É importante destacar que o foco não deve ser em como a Eugenia produziu o racismo na Educação, mas nos processos pelos quais o racismo utilizou a Eugenia e o discurso científico para se estruturar na sociedade, atravessando as práticas culturais das instituições educativas e a reprodução das ações individuais.

Sendo um discurso científico que educa para a exclusão de certos corpos, há um padrão de corpo que é projetado socialmente como o desejável. A função das instituições seria a de propiciar as formas de sua estruturação. Dentre os caminhos para essa exclusão que estão presentes no Boletim de Eugenia, analisaremos a seguir as propostas voltadas para a reprodução humana e as relações sexuais.

\section{Educação Sexual: quem tem o direito de nascer?}

Outro tema recorrente no Boletim de Eugenia são os que lidam com a Educação Sexual. Uma vez que a Eugenia propunha a manutenção das "boas sementes germinativas", as formas de controle da natalidade se tornaram elementos imprescindíveis para o desejado aumento da população a partir de um "tipo eugênico" ideal. De acordo com Bolsanello (1996), se a percepção na época era a de que o brasileiro não tinha conseguido se desenvolver dada a sua preguiça, ociosidade, indisciplina e pouca inteligência devido ao calor e à mistura com o que era considerado "raças inferiores", pelo menos o que era visto enquanto um problema racial poderia ser solucionado, já que contra o clima não havia soluções.

Pelo seu fundamento racista, as propostas de esterilização e controle da natalidade eram voltadas majoritariamente para as pessoas não-brancas. Podemos constatar isso em trecho de artigo intitulado "Esterilização para aperfeiçoamento humano", escrito por Renato Kehl e publicado no número 12 do ano de 1929:

Tomando por base o recenseamento de 1872, em que foram computados 8.419 .672 habitantes livres e 1.510.896 escravos, calculava-se existiam então 1.954 .452 
individuos de proveniência legitimamente africana, 386.955 de 'raça americana' e 3.801.782 de mulatos e mestiços. Pode-se bem imaginar o valor ethnico, o valor eugênico, o valor social e econômico da população brasileira resultante de tal mistura heterogênea e heterochromica. Tendo em vista a diferença de densidade das três camadas sociaes, - uma levíssima, de brancos, outra leve, de typos médios, e uma terceira macissa, de inferiorizados, não poderei deixar de opinar, favoravelmente, pela propaganda da limitação da natalidade no nosso paiz, sobretudo entre os indivíduos componentes da ultima camada. Direi, pois, com toda sinceridade, que é indispensável e urgente divulgar entre as pessoas pobres e incultas, a necessidade de restringir a natalidade, ao mesmo tempo que se lhes ensina os meios mais práticos de alcançar esse desideratum.

Para tais fins, iniciam-se as campanhas do que passou a ser considerada uma "profilaxia matrimonial”. Segundo afirmativas de Renato Kehl: "Nunca serão resolvidos os problemas dos crimes, dos males sociaes, enquanto não for cuidado, em primeiro logar, a questão da prophylaxia matrimonial" (Boletim número 18, ano 1930). Os eugenistas buscavam as melhores sementes germinativas ao estudarem o parentesco e, dessa forma, propunham medidas para evitar os casamentos considerados indevidos e cuja prole gerada atrasaria o desenvolvimento da sociedade brasileira.

Por ser considerado de grande relevância para a Eugenia, o número 24 do Boletim, publicado no ano de 1930, traz praticamente todo o seu conteúdo voltado para a Educação Sexual. Para a composição desse número, um inquérito foi organizado, convidando especialistas a escreverem sobre o assunto. Pela primeira vez aparece uma definição mais concisa do que os eugenistas chamam de Educação Sexual. Nesse número do Boletim de Eugenia, de acordo com a Dra. Paulina Luisi (de Montevidéu), a Educação Sexual é considerada uma "acção pedagógica que pretende submeter o instincto sexual a acção da vontade sob o dominio da intelligencia instruída, consciente e responsável".

Nesse mesmo número também encontramos uma série de recomendações sobre a necessidade da ação pedagógica, nas instituições escolares, ser conduzida por professores (para os meninos) e professoras (para meninas). Algumas exceções ocorrem a essa regra, sugerindo que caberia às mulheres o papel de educadoras sexuais, dada a sua maior compreensão e cuidado com o tema para as crianças. É nessa mesma época que também circulava outro periódico intitulado "A Mãe de Família”. Para não alongar nessas considerações e dado o objetivo aqui de se demonstrar o viés racista dessa proposta de Educação Sexual, destaco alguns importantes pontos.

Primeiro, perceber a Educação Sexual enquanto uma ação pedagógica que pretende submeter o instinto sexual a um suposto controle, nos leva aos recorrentes casos históricos de estupro de mulheres negras e indígenas por homens brancos. Uma das concepções da época era a de que tais homens sucumbiam a um "instinto animal". Ligada a essa percepção, encontramos em anos posteriores do Boletim de Eugenia uma série de artigos escritos por três pessoas diferentes, sendo elas o Prof. Luiz L. Silva ("Cruzamento do branco com o preto”, publicado no Boletim número 30, ano 1931), o Prof. Herman 
Lundborg ("Cruzamento de raças", publicado no Boletim número 34, ano 1931) e o Prof. S. de Toledo Piza Junior ("O que pode resultar do casamento entre o branco e o preto", publicado no Boletim número 37, ano 1932; “O casamento do branco com o preto a luz da Biologia, publicado no Boletim número 38, ano 1932; "A hereditariedade da cor da pele no casamento branco-preto", publicado no Boletim número 41, ano 1933).

No ano de 1931, o Prof. Luiz Silva pergunta se era razoável o casamento do branco com o preto e de modo incisivo afirma que "não, absolutamente não. E ainda mais, nem razoável nem decente". O referido autor considera que a teratologia (especialidade médica que se dedica ao estudo das anomalias e malformações ligadas a uma perturbação do desenvolvimento embrionário ou fetal), considerada pelo mesmo "o capítulo das monstruosidades", aumenta cada vez que raças diametralmente opostas se unem. Para sustentar o seu argumento da oposição e diferenciação racial entre brancos e pretos, o pesquisador recorre a frenologia, índices craniométricos e cefálicos:

O branco, sempre considerado como raça superior, é orthognatha, tem o ângulo facial apurado e o índice cefálico tão exagerado que, sem a menor duvida, marca o sensível afastamento das espécies inferiores. Isso prova que o homem tende a evoluir psychicamente, apurando os sentimentos e desprezando os instinctos. O negro mora do lado oposto. Como constituinte da raça inferior, o negro é prognatha, tem o ângulo facial exagerado e índice cefálico quasi nullo. Ninguem ignora que o índice cefálico é a expressão da espiritualidade e o ângulo facial reflecte a animalidade. (...) $\mathrm{O}$ prognathismo no negro, devido ao excessivo desenvolvimento dos três grossos molares e dos caninos, tal como nos símios, marca uma grande e indiscutível animalidade.

Um dos efeitos deletérios do racismo é a associação dos seres humanos a uma condição de animalidade, remetendo-os ao "reino dos instintos" e distanciados do controle racional que só as mentes consideradas mais elevadas poderiam alcançar. Para o Prof. Luiz Silva, "da união matrimonial de elementos raciais tão diferentes, só uma deducção poderemos fazer: trata-se de um matrimonio de instinctos e não de sentimentos". Mais adiante assegura que "(...) o branco, desgraçadamente, deu provas da sua degenerescência moral, da sua escravidão aos instinctos, pois abdicou o direito racial pelo direito erótico-convulsivo da matéria, pelo grito da bestialidade que caracteriza os seres inferiores".

Aqui encontramos uma conexão entre tais afirmativas e a concepção de Educação Sexual estabelecida pela Dra. Paulina Luisi. Por sua vez, o Prof. Herman Lundborg (Diretor do Instituto de Biologia Racial de Upsala - Suécia) afirma que a mistura racial constitui uma espada de dois gumes, não recomendando a mestiçagem e combatendo o cruzamento de raças consideradas biologicamente muito diferentes. O seu tom racista se torna evidente:

Mas ainda existem largos círculos de opinião que não vem ou não querem ver nenhum perigo na mistura de brancos com gente de cor. Os representantes de 
certos movimentos filantrópicos, políticos e religiosos aplainam o caminho para essas mestiçagens (...). O psiquiatra norueguês Vogt (1914) acentua igualmente: 'Não convém a um europeu do norte, louro, de olhos azues, inteligente, rebaixar a sua massa hereditária casando-se com uma negra'.

Mas se os traços fenotípicos podem ser critérios evidentes para um europeu do norte, como essa característica poderia ser levada em consideração nas terras brasileiras? Como exposto em páginas anteriores, a mestiçagem brasileira era o imbróglio das teorias eugenistas produzidas em "terras americanas". Através da Genética buscavam-se as melhores relações de parentesco, conforme podemos perceber em trecho de artigo escrito pelo Prof. S. de Toledo Piza Junior:

Há mulatos de todas as tonalidades. Os quasi pretos confundem-se com os pretos puros, bem como os quasi brancos com os brancos puros. Qualquer que seja, porém, a cor aparente do mestiço, ele possue na sua estrutura intima os gens para a outra cor, os quais, em ocasião oportuna, poderão manifestar-se. Um casal de indivíduos na aparência perfeitamente brancos, desconhecendo a arvore genealógica da sua família, não deverão assustar-se si vierem a conceber, um dia, um bebezinho preto.

No número seguinte ao desse artigo, o mesmo Prof. S. de Toledo Piza Junior complementa as suas afirmações. Para tal, faz amplo uso de terminologia científica da Genética, tecendo explicações sobre gametas, gametogênese, cromossomos, pares homólogos, haploidia e diploidia. Chega inclusive a fornecer uma ilustração sobre a divisão cromossomática. Tudo isto para tecer sua argumentação sobre o processo no "mestiço humano".

Depois de sucessivos artigos, no ano de 1933, o citado autor expõe as suas considerações. Para o mesmo, a depender do ponto de vista que se encara a questão, as uniões entre o branco e o preto podem ser consideradas na perspectiva da Zoologia, da Genética, da Eugenia e do Antropológico. O autor considera que o branco e o preto são diferentes sobre variados aspectos e que, por isso, deveriam ser considerados enquanto espécies distintas. Mesmo assim, se reconhece que entre ambos parece não haver uma repulsa natural, apesar de que "no amago de cada um, nas trevas do inconciente, essa aversão biológica deve forçosamente existir". O Prof. S. de Toledo Piza Junior conclui o seu artigo afirmando:

Por essas poucas razões pensamos poder concluir, que debaixo do ponto de vista antropológico, as uniões de branco com preto não são naturais. Finalmente, consideremos a questão, do ponto de vista social. É exatamente aqui, onde o assunto se presta para os mais longos debates, que vamos gastar o menor numero de palavras. Limitar-nos-emos simplesmente a dizer, que através do prisma social, o casamento do branco com o preto, quaisquer que sejam as vantagens que disso advenham para o individuo ou para a comunidade, deve ser considerado, na situação presente, como uma união repugnante. 
O que podemos perceber diante de todas as evidências elencadas até este ponto é a de que o Boletim de Eugenia, enquanto forma de Educação e Divulgação Científica, efetuava uma propaganda racista na qual preteria as populações negras em comparação às pessoas mais próximas de um padrão de brancura. Logo, através de uma narrativa ancorada em um discurso científico, havia uma forma de exercer e manter a branquitude nos lugares de poder. Consolidava-se a percepção de que a brancura da pele, junto com outros traços fenotípicos e comportamentais, eram os ideais para as pessoas serem consideradas civilizadas.

Há um processo civilizatório racista no qual o Boletim de Eugenia se insere na estrutura como um dos elementos de consolidação desse poder. Se outrora eram essas publicações que reverenciavam o lugar do branco como ser superior, ao passar dos anos, se a Eugenia cai em descrédito (pelo menos explicitamente) e publicações desse tipo não são mais produzidas, os livros didáticos, em muitas ocasiões, persistem com as mesmas representações de inferioridade associadas às populações racializadas como não-brancas (Oliveira, 2003; Oliveira, 2017; Silva, 2011).

A partir da análise dos exemplares do Boletim de Eugenia aqui apresentadas, vislumbramos aspectos inextrincáveis das Ciências com as relações sociais, econômicas, políticas e educacionais das situações históricas em análise. Com o uso educacional da História das Ciências, a perspectiva de ensino possibilita conexões entre acontecimentos tidos no passado e de suas reverberações na atualidade, seja em sua atual permanência ou supressão na sociedade.

\section{Usos educativos da História das Ciências}

De acordo com Teixeira e Silva (2017),

(...) a história da eugenia oferece aos professores de biologia temas que podem ser usados em sala de aula para uma abordagem crítica do ensino da genética tais quais a relação entre ciência e sociedade, a natureza da ciência e implicações éticas e morais do trabalho científico.

Várias são as pesquisas que indicam a importância de um Ensino de Ciências e de uma Educação Científica que germine, nos estudantes, o senso crítico da cidadania para a tomada de decisões tendo como fundamento os princípios da argumentação científica (Auler, 2007; Krasilchik, 1987; Krasilchik \& Marandino, 2007; Praia et al., 2007).

Tais estudos, a partir de uma perspectiva que envolva a Ciência, a Tecnologia, a Sociedade e o Ambiente (CTSA), buscam responder questões importantes que podem ser resumidas na pergunta "para quem e para que ensinamos ciências?" (Auler, 2007; Auler \& Delizocoiv, 2001). Reconhecendo a possibilidade de utilizarmos a História, a Filosofia e a Sociologia das Ciências (HFSC) na Educação Básica (Moura \& Guerra, 2016), é imprescindível de que essas reflexões históricas não se atenham a um passado julgado ultrapassado. As ideias eugênicas, por mais que não sejam explicitamente veiculadas na sociedade atual, ainda se encontram com outras roupagens. 
A História e a Filosofia das Ciências podem contribuir substancialmente para esse processo, apesar de que as mesmas também devem ser descolonizadas. Para Gagliardi (1988), a História e a Epistemologia das Ciências podem ser utilizadas para a discussão sobre a produção, apropriação e controle dos conhecimentos em nível social e individual. Nesse caso, "a epistemologia pode permitir mostrar como se reproduzem e se naturalizam as ideias dominantes na sociedade, ou seja, como se constrói e se reproduz a ideologia dominante" (Gagliardi, 1988, p. 295).

Há uma importante questão a se lidar pelo fato de reconhecer a HFSC como perspectiva educativa. A questão aqui trata de perceber o racismo estruturado na sociedade brasileira e, no caso da Educação, de buscarmos práticas educativas que se guiem pelas seguintes perguntas:

Com que escola o Brasil se produziu (e continua a ser produzido) como nação? Como ela tem desenvolvido o seu trabalho de preparação dos brasileiros para a vida nacional? Em torno de que mitos, ideias e projetos produz a homogeneização dos brasileiros? Como combate os grupos não desejáveis à sua ideia de nacional, de brasileiro? Como essas construções ideológicas se expressam nas práticas escolares? Como reconhecê-las? Como combater aquelas que violentam simbolicamente indivíduos identificados com grupos discriminados? (Beserra \& Lavergne, 2018, p. 30)

A partir da análise do Boletim de Eugenia e indicado, de forma geral, por Beserra e Lavergne (2018, p. 62),

(...) o racismo se utiliza de estereótipos produzidos em torno de referências como raça, etnia e sexo, mas, se necessário, pode transcendê-las e criar ou se basear em novas categorias para justificar o que geralmente busca encobrir: a exploração de classes e a desigualdade social.

Em qualquer das suas expressões, o racismo é um recurso ideológico da dominação, atribuindo à natureza o que é da ordem do social e histórico, buscando explicar a desigualdade social pelas diferenças fenotípicas, étnicas ou sexuais.

Romper o silêncio nos cursos de Biologia sobre a questão racial é desafiador, pois envolve, no caso dos cursos de formação docente, uma formação na qual as/os profissionais estejam dispostas/os a falar e conduzir atividades para a reeducação das relações étnico-raciais (Fernandes, 2015). Para isso, os professores e professoras devem refletir criticamente sobre os lugares que ocupam no âmbito das relações étnico-raciais, sobretudo as pessoas que são consideradas brancas, pelo fato de que historicamente elas não se percebem em suas relações sociais enquanto indivíduos também racializados e detentores de lugares de privilégio.

Apple (2001) indica que para considerarmos a história econômica, política, legal, da saúde, educacional e de fato, de todas as instituições, devemos colocar como dinâmica central a política da branquidade. A partir disso, muitos elementos que podem soar como progressistas demonstrariam o poder das narrativas hegemônicas e de como estas 
apagam da memória histórica questões específicas de diferença e de opressão. Para o autor, para consolidar uma prática pedagógica antirracista, tornar-se-ia imprescindível atentarmos para a invisibilidade da branquidade, dando mais atenção à "identidade branca" quando esta não se coloca como elemento racializado (uma "presença ausente") e que fala por um segmento específico, mas enquanto "humanidade padrão" podendo falar sobre e para todos.

No processo de formação de professores e professoras de Ciências e Biologia, para Carvalho e Gil-Pérez (2011), deve-se: conhecer a matéria a ser ensinada; conhecer e questionar o pensamento docente espontâneo; adquirir conhecimentos teóricos sobre a aprendizagem e aprendizagem de Ciências; possuir capacidade de crítica fundamentada no ensino habitual; saber preparar atividades; saber dirigir a atividade dos alunos; saber avaliar; utilizar a pesquisa e a inovação. Tendo em vista a reflexão sobre o lugar da "pessoa branca" na sociedade, os docentes devem se questionar sobre o que eles próprios pensam sobre a raça, sendo críticos sobre os materiais didáticos utilizados e veiculados para as suas práticas educativas.

Se a Eugenia, enquanto campo discursivo, possui um percurso relativamente recente na história do Brasil, há possibilidades concretas de que muitas destas práticas ainda persistam em materiais de ensino e/ou nas práticas cotidianas de muitos docentes que foram formados a partir dessa ótica. É o caso de conceitos sobre processos de aprendizagem que estão por trás de atitudes consideradas inerentes às escolas e que refletem ideias de segregação, a exemplo da separação de turmas "fortes e fracas" ou filas de cadeiras com alunos separados por notas obtidas em avaliações (Gioppo, 1996).

Ressalto, mais uma vez, que a compreensão sobre raça sempre esteve presente na construção da Nação, traço marcante e presente nas diversas instituições de conhecimento existentes no Brasil desde pelo menos a chegada da Família Real (Schwarcz, 1993). Em um país como o Brasil, no qual o processo de formação da sociedade e de organização política se funda a partir dos conceitos sobre raça (por isso não há sentido discutir sobre cidadania, democracia, projeto de Educação e Nação caso não se reconheçam as relações entre raça e racismo), é preciso que tais assuntos sejam postos em pauta.

Dada a contribuição das Ciências Biológicas em consolidar uma visão biológica de raça na sociedade, cabe às mesmas o compromisso de desfazer essa associação, mas sem esvaziar conceitualmente a discussão sobre as relações raciais. Isso implica tanto trazer à tona os processos históricos de consolidação do racismo científico (como o que foi até este momento apresentado através dos exemplares do Boletim de Eugenia), quanto de estabelecer narrativas pelas quais possamos refletir sobre as relações sociais e políticas na contemporaneidade. Se atenção deve ser dada ao trato com a dimensão conceitual das Ciências (aquelas relativas à Genética, por exemplo) associadas a essas questões, essa não deve ser a única perspectiva que vise fomentar práticas antirracistas. As Leis 10.639/03 e 11.645/08, para além da inserção de novos conteúdos curriculares, fazem referência as relações entre as pessoas, o desenvolvimento de atitudes cooperativas e princípios éticos condizentes à aceitação da vida em sua diversidade. 
Aproximando-se do final deste trabalho, destaca-se o dever na busca por um Ensino de Ciências (nesse caso com ênfase nas Ciências Biológicas) que para além do desenvolvimento de conteúdos curriculares, reconheça os lugares de privilégio estruturais que as pessoas brancas ocupam na dinâmica da vida social. Lugar este construído no plano científico (através da Eugenia e do racismo científico), mas principalmente através de um sistema de opressões historicamente atualizado. Configura-se, portanto, uma proposta educativa que não se atenha à dimensão conceitual, mas aos espaços que possam questionar as relações assimétricas de poder cunhadas na raça. Por essa via, a pesquisa educacional historiográfica, no que possibilita em olhar para o passado, assumir o presente e buscar outro futuro possível, constitui-se em valiosa ferramenta.

\section{Educar no antirracismo, educar para o nunca mais...}

A “educação para o nunca mais", para Candau e Sacavino (2013), promove o sentido histórico e a importância da memória em lugar do esquecimento. Inserir o tema da Eugenia e do racismo científico nos currículos escolares (Educação Básica e Superior) requer situar as Ciências Biológicas e a elaboração de uma malha discursiva na qual a técnica para a morte/matar está presente.

Lidar com as memórias, nesse caso com a História das Ciências Biológicas, pressupõe um processo de aflorar dores não somente dos oprimidos, mas daqueles que historicamente causaram as relações de opressão (Léo Neto \& Mota, 2019). É importante ressaltar que re-conhecer ${ }^{5}$ o processo histórico implica tanto perceber os passos dados quanto sentir o lugar ocupado atualmente. Torna-se imprescindível perceber o lugar no qual o observador faz as suas observações e emite o seu discurso, assim recomendado por Maturana (2014) em sua "Biologia do Conhecer". Com isto, a contemporaneidade fará profundas conexões com um passado, até porque, memórias são construções (a) temporais.

Não basta um retrospectivo histórico se a partir disso não conseguirmos criar pontes e atentar para as semelhanças, por exemplo, dos "programas policialescos" da mídia televisiva e de uma "criminologia racial/racista" (na qual expõe o corpo negro e consolida uma imagem estereotipada e racista do "bandido"), de políticas públicas que incentivam abstinências sexuais (semelhante a uma contemporânea "profilaxia matrimonial", para utilizar o mesmo termo encontrado no Boletim de Eugenia), de discursos de representantes do Governo Federal com elementos racistas (a "evolução" de indígenas que se assemelham aos humanos brancos ou a "malandragem" do negro que foi herdada pela população). Se no período histórico analisado identificamos a consolidação de uma narrativa que através da Ciência endossou as relações de opressão de brancos para com a população negra, contemporaneamente esses traços permanecem na sociedade nem tanto através do discurso científico, mas a partir da estrutura de

5 Utilizo propositadamente a grafia "re-conhecer" ao invés de "reconhecer" para enfatizar que já há um conhecimento sobre algo e o que necessitamos visando o "educar para o nunca mais" é de uma recursividade autopoiética que nos faça re-conhecer a partir do que supostamente conhecemos. Neste caso, re-conhecer os privilégios raciais. 
dominação que se atualiza ao longo dos anos para a manutenção dos privilégios.

Em todas essas violências, a necropolítica racista, genocida e epistemicida se faz presente. Explicitamente ou não, há nesses casos contemporâneos sementes eugênicas que insistem em germinar. Qual a relação então que poderíamos traçar entre as Ciências Biológicas, a Educação e as situações históricas aqui analisadas? Mais uma vez recorrendo a Maturana (2014), olhar para o lugar no qual o discurso é emitido implica que as nossas práticas educativas antirracistas não devem ser somente sobre o cotidiano, mas no cotidiano. Isso implica uma prática pedagógica engajada que ensina a transgredir visando as práticas de liberdade (Hooks, 2013).

Relembrando Mbembe (2016, p. 135), se "a soberania é a capacidade de definir quem importa e quem não importa, quem é 'descartável' e quem não é”, tanto em corpos quanto em conhecimentos, relaciono que a ausência nos currículos escolares de certos temas indica o que pode ser "descartável" e que colabore na manutenção dos silêncios e dos privilégios racializados das pessoas consideradas brancas. Os signos e símbolos que estipulam rótulos e categorias discriminatórias que procedem à exclusão permanecem em alguns discursos (Sanchez-Arteaga et al., 2015). Dessa forma, também podemos perceber o discurso escolar enquanto "processo de alterização" no qual "o outro" é delimitado em suas fronteiras, transformado em suportes de dominação a exemplo do racismo e do sexismo. Contudo, é importante ressaltar que se o racismo possui como efeito a desumanização da vítima, o mesmo racismo também desumaniza quem o comete.

Lidar com esses temas na Educação (na educação básica e/ou no ensino superior) necessariamente deve passar pelo reconhecimento crítico dos mecanismos de produção dos espaços de privilégio das pessoas consideradas brancas na sociedade brasileira. Ao dizer isto, indico as questões relacionadas a branquitude que perpassam o discurso eugênico, tanto no que ele implica de controle da taxa de natalidade da população, mas também dos espaços nos quais o discurso científico é produzido, legitimado e repercutido politicamente. Branquitude não deve ser associada à Negritude, uma vez que os processos sociais que permitem a formação desses conceitos são diferenciados. Como dito anteriormente, a branquitude consiste em um sistema de privilégio estrutural mantido através de relações assimétricas de poder, implicando opressões e, consequentemente, a figura de um opressor cuja subjetividade autocentrada e egóica faz com que os corpos brancos se ponham em relação de dominação aos corpos não-brancos.

Por mais que isso possa evocar a imagem de relações inter-raciais cuja violência seja mais explícita, a relação com a alteridade ocorre nas entrelinhas do cotidiano. Podem ser tomadas como exemplos dessas situações as representações sobre qual conhecimento científico é válido (especificamente referindo-se ao lugar de origem e fenótipo de quem o produziu), a preterição afetiva, a hipersexualização de homens e mulheres negras, condicionantes fenotípicas associadas à padrões de beleza, a solidão e exclusão de crianças negras nas brincadeiras das escolas. 
A Escola e a Universidade, enquanto espaço de socialização e de encontro de culturas (Sasseron, 2015), estão atravessadas por esses processos. Por essas instituições de conhecimento majoritariamente se ancorarem em uma perspectiva brancocentrada, também são nelas (e por elas) que violências raciais podem ser perpetuadas, mantidas e estruturadas na sociedade. Contudo, se da mesma forma que podem ter o racismo instituído em suas práticas, também se constituem em terreno fértil para o estabelecimento de saberes e práticas voltadas a educação antirracista. Educar para o nunca mais, com subsídios educativos da História das Ciências em uma perspectiva racializada, se apresenta como uma proposta educativa na qual a pessoa branca não se perceba enquanto "centro do mundo".

Como busquei ter demonstrado ao longo deste trabalho, às Ciências Biológicas e, neste caso, ao Ensino de Biologia, recaem importantes e necessárias condições éticas no que se refere à concretização de práticas de combate à todas as formas de discriminação.

\section{Agradecimentos}

A Coordenação de Aperfeiçoamento de Pessoal de Nível Superior (CAPES), pela concessão de uma bolsa de pós-doutoramento, através do Programa Nacional de Pós-Doutorado (PNPD), vinculada ao Programa de Pós-Graduação em Educação e Contemporaneidade (PPGEDUC/UNEB). À professora Kelly Meneses Fernandes (UNEB), doutoranda do PPGEFHC/UFBA, pela leitura atenciosa, troca de opiniões e sugestões que ajudaram no aprofundamento do trabalho.

\section{Referências $^{6}$}

Auler, Décio. (2007). Enfoque Ciência-Tecnologia-Sociedade: Pressupostos para o contexto brasileiro. Ciência \& Ensino (1), 1-20.

Auler, Décio, \& Delizocoiv, Demétrio. (2001). Alfabetização Científico-Tecnológica para quê? Ensaio Pesquisa em Educação em Ciências, 3(1), 122-134. https://doi. org/10.1590/1983-21172001030203

Apple, Michael. (2001). Políticas de direita e branquidade: a presença ausente da raça nas reformas educacionais. Revista Brasileira de Educação, (16), 61-67. https://doi. org/10.1590/S1413-24782001000100007

Azevedo, Célia Maria. (1987). Onda negra, medo branco: O negro no imaginário das elites- século XIX. Paz e Terra. 267p.

6. Me alinho à perspectiva da professora Dra. Bárbara Carine Soares Pinheiro, em artigo publicado no volume 19 desta revista intitulado "Educação em Ciências na escola democrática e as relações étnico-raciais" ao afirmar, em nota de rodapé, que por trabalhar com questões de diversidade adota a inserção de nome e sobrenome completo das autorias. De acordo com a pesquisadora, isto se deve pelo fato de evitar a generalização androcêntrica de que a produção de conhecimento científico cabe somente aos homens. Das referências aqui utilizadas, aproximadamente metade são de mulheres cientistas e, portanto, para auxiliar na identificação do que foi produzido por homens e mulheres, também faço essa escolha. Tal qual a Professora Dra. Bárbara Pinheiro, tomo isso como uma postura política. 
Beserra, Bernadete de Lourdes Ramos, \& Lavergne, Rémi Ferdinand. (2018). Racismo e educação no Brasil. Ed. UFPE. 165p.

Bizzo, Nélio Marco Vincenzo. (1995). O paradoxo social-eugênico, genes e ética. Educar em Revista (11), 45-61. https://doi.org/10.1590/0104-4060.141

Bolsanello, Maria Augusta. (1996). Darwinismo social, eugenia e racismo "científico" - sua repercussão na sociedade e na educação brasileiras. Educar em Revista, (12), 153165, https://doi.org/10.1590/0104-4060.166

Bonfim, Paulo Ricardo. (2019). Educação Eugênica: As recomendações de Renato Kehl a educadores, pais e escolares. History of Education in Latin America, 2, 2-16.

Candau, Vera Maria Ferrão, \& Sacavino, Susana Beatriz. (2013). Educação em direitos humanos e formação de educadores. Educação, 36(1), 59-66.

Carlos, Anderson Ricardo, \& Dietrich, Ana Maria. (2018). Eugenia no Brasil: Reflexões sobre raça, miscigenação e Direitos Humanos para a educação científica. In Anais do 16 Seminário Nacional de História da Ciência e da Tecnologia, Campina Grande, Paraíba.

Carula, Karoline. (2016). Darwinismo, Raça e Gênero: Projetos modernizadores da nação em conferências e cursos públicos (Rio de Janeiro, 1870-1889). Editora da Unicamp.

Carvalho, Anna Maria Pessoa, \& Gil-Perez, Daniel. (2011). Formação de professores de Ciências: Tendências e inovações. Cortez.

Fernandes, Kelly Meneses. (2015). Biologia, educação das relações étnico-raciais e inversão epistemológica. Revista Interinstitucional Artes de Educar, 1(2), 311-323.

Gagliardi, Raúl. (1988). Como utilizar la Historia de las ciencias en la enseñanza de las ciencias. Enseñanza de las Ciencias, 6(3), 291-296.

Gioppo, Christiane. (1996) Eugenia: a higiene como estratégia de segregação. Educar em Revista, (12), 167-180, https://doi.org/10.1590/0104-4060.167

Guimarães, Antônio Sérgio Alfredo. (2009). Racismo e Antirracismo no Brasil. 3ed. Editora 34.

Guimarães, Juarez, \& Drumond, André. (2018). A Longa Temporalidade do Estado Racialista e o Impasse da República Democrática no Brasil. Mediações-Revista de Ciências Sociais, 23(2), 123-159, http://dx.doi.org/10.5433/2176-6665.2018v23n2p123

Hooks, Bell. (2013). Ensinando a transgredir: A educação como prática da liberdade. Editora Martins Fontes.

Krasilchik, Myriam. (1987). O professor e o currículo das Ciências. EPU.

Krasilchik, Myriam, \& Marandino, Martha. (2007). Ensino de Ciências e cidadania. Moderna. 
Léo Neto, Nivaldo Aureliano, \& Mota, Sueli Ribeiro. (2019). Flores e Dores: Emoções e a ética da vida para um ensino de ciências e biologia intercultural e antirracista. Revista Temas em Educação, 28(2), 83-10.

Maturana, Humberto. (2014). Cognição, ciência e vida cotidiana. Editora UFMG.

Mbembe, Achille. (2016). Necropolítica. Arte \& Ensaios, 32.

Moraes, Roque. (2003). Uma tempestade de luz: a compreensão possibilidade pela análise textual discursiva. Ciência \& Educação, 9(2), 191-211, http://dx.doi.org/10.1590/S151673132003000200004

Moura, Cristiano Barbosa, \& Guerra, Andreia. (2016). História Cultural da Ciência: Um Caminho Possível para a Discussão sobre as Práticas Científicas no Ensino de Ciências? Revista Brasileira de Pesquisa em Educação em Ciências, 16(3), 725-748.

Munanga, Kabengele. (1996). Mestiçagem e experiências interculturais no Brasil. In L., Schwarcz, \& L. S., Reis (Orgs.). Negras imagens. Editora da Universidade de São Paulo/ Estação Ciência.

Oliveira, Teresinha Silva. (2003). Olhares que fazem a "diferença": O índio em livros didáticos e outros artefatos culturais. Revista Brasileira de Educação, (22), 25-34.

Oliveira, Rosana Medeiros (2017). Descolonizar os livros didáticos: Raça, gênero e colonialidade nos livros de educação do campo. Revista Brasileira de Educação, 22 (68), $11-33$.

Praia, João, Gil-Pérez, Daniel, \& Vilches, Amparo. (2007). O papel da natureza da ciência na educação para a cidadania. Ciência \& Educação 13(2), 141-156, https://doi. org/10.1590/S1516-73132007000200001

Sánchez-Arteaga, Juanma, Rasella, Davide, Garcia, Laia Ventura, El-Hani, Charbel Niño. (2015). Alterização, biologia humana e biomedicina. Scientiae Studia, 13(3), 615-41, https://doi.org/10.1590/S1678-31662015000300007

Sasseron, Lúcia Helena. (2015). Alfabetização científica, ensino por investigação e argumentação: relações entre ciências da natureza e escola. Ensaio Pesquisa em Educação em Ciências, 17, 49-67, https://doi.org/10.1590/1983-2117201517s04

Schuchman, Lia Vainer. (2012). Entre o "encardido", o "branco" e o "branquíssimo": Raça, hierarquia e poder na construção da branquitude paulistana. (Tese de Doutorado em Psicologia). Universidade de São Paulo, São Paulo.

Schwarcz, Lilian Moritz. (1993). O Espetáculo das raças - cientistas, instituições e questão racial no Brasil, 1870-1930. Companhia das Letras.

Silva, Ana Célia da. (2011). A representação social do negro no livro didático: O que mudou? por que mudou? EDUFBA. 182p. 
Silva, Priscila Elisabete. (2015). Um projeto civilizatório e regenerador: Análise sobre raça no projeto da Universidade de São Paulo (1900-1940). (Tese de Doutorado em Educação). Universidade de São Paulo, São Paulo.

Teixeira, Izabel Mello, \& Silva, Edson Pereira. (2017). História da eugenia e ensino de genética. História da Ciência e Ensino, 15, 63-80, https://doi.org/10.23925/21782911.2017v15p63-80

Verrangia, Douglas. (2014). Educação científica e diversidade étnico-racial: O ensino e a pesquisa em foco. Interacções, 31, 2-27, https://doi.org/10.25755/int.6368

Nivaldo Aureliano Léo Neto

Universidade Estadual do Ceará Fortaleza, Ceará, Brasil

nivaldoleo@gmail.com

Editora Responsável

Maíra Batistoni e Silva

Manifestação de Atenção às Boas Práticas Científicas e de Isenção de Interesse

Os autores declaram ter cuidado de aspectos éticos ao longo do desenvolvimento da pesquisa e não ter qualquer interesse concorrente ou relações pessoais que possam ter influenciado o trabalho relatado no texto. 